\title{
Özgün Çalışma
}

\section{Morbid Obezite Tedavisinde, Roux En-Y Tipi Gastrik By-Passın Uzun Dönem Sonuçları ve Eşlik Eden Hastalıklar Üzerine Olan Etkisi; Morbid Obezite Cerrahisinin Emekleme Dönemi}

\section{Roux En-Y Type Gastric Bypass Long-Term Results and Effects on Concomitant Diseases in the Treatment of Morbid Obesity; Infancy Period of Morbid Obesity Surgery}

\author{
Ergün Yüksel ${ }^{1}$, Mehmet Akif Üstüner ${ }^{2}$, Mehmet Mihmanli ${ }^{3}$ \\ ${ }^{1}$ SBÜ. Dr. Abdurrahman Yurtaslan Ankara Onkoloji Eah Genel Cerrahi Kliniği \\ ${ }^{2}$ SBÜ. Gülhane Eğitim ve Araştırma Hastanesi Gastroenteroloji Cerrahi Kliniği \\ ${ }^{3}$ SBÜ. Şişli Hamidiye Etfal EAH Genel Cerrahi Kliniği
}

\begin{abstract}
Introduction: Morbid obesity is a multifactorial disease that is a major health problem all over the world. In this study, we presented the first two-year follow-up of patients who underwent conventional Roux En-Y Type Gastric Bypass (RYGB) performed in the years when obesity surgery has just begun in our country.

Methods: In our study, pre-and post-operative data of 15 patients who underwent RGYB due to morbid obesity.

Results: The data of 15 patients, 6 male (40\%) and 9 female $(60 \%)$, were evaluated in the study. The mean age of the patients was $38 \pm 12.90$ (24-63) years in all cases and $31.5 \pm 8.16$ (24-46) years in men and $42.33 \pm 14.02(26-63)$ years in women. In the preoperative evaluation of patients in terms of concomitant diseases, it was determined that $47 \%$ of the patients had HT $(n=7), 20 \%(n=3)$ Type II $\mathrm{DM}, 6.67 \%(\mathrm{n}=1)$ hypermenorrhea, $6.67 \%(\mathrm{n}=1)$ venous ulcers in the lower extremity, $13.34 \%(\mathrm{n}=$ 2) menstrual cycle irregularity, $6.67 \%(\mathrm{n}=1) \mathrm{UAS}, 6.67 \%(\mathrm{n}=1)$ chronic obstructive pulmonary disease (COPD), $20 \%(n=3)$ Hepatosteatosis.

Discussion and conclusion: Conventional RYGB surgery is one of the first morbid obesity surgeries performed in our country. It is a safe method in the treatment of morbid obesity, which enables patients to lose weight and at the same time to recover from obesity induced by comorbid diseases, and causes a significant change in the quality of life of patients.
\end{abstract}

Keywords: Morbid obesity, conventional roux en-y gastric by-pass, obesity surgery, quality of life

\section{ÖZET}

Giriş ve amaç: Morbid obezite, tüm dünyada önemli bir sağlık problemi olan multifaktoriyel bir hastalıktır. Bu çalışmada obezite cerrahisinin ülkemizde yeni başladığı yıllarda yapılan konvansiyonel Roux En-Y Tipi Gastrik By-Pass (RYGB) uygulanan hastaların ilk iki senelik takiplerini sunduk.

Yöntem ve gereçler: Çalışmamızda 2005-2007 yılları arasında morbid obezite nedeniyle RGYB uygulanan 15 hastaya ait operasyon öncesi ve sonrası veriler restrospektif olarak incelendi. Tüm hastalara ameliyat öncesi ve ameliyattan 1 y1l sonraki dönemde SF-36 Quality Life formu (sağl1kla ilgili yaşam kalitesini ölçen form) ile yaşam kalitesi değerlendirildi.

Bulgular: Çalışmada 6'sı (\% 40) erkek, 9'u (\% 60) kadın toplam 15 hastaya ait veriler değerlendirildi.

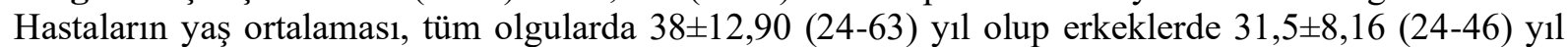
kadınlarda 42,33 $\pm 14,02$ (26-63) yıl olarak saptandı. Hastaların eşlik eden hastalıklar açısından ameliyat öncesi değerlendirilmelerinde; \% 47'sinde (n=7) HT, \% 20'sinde (n=3) Tip II DM, \% 6,67'sinde (n=1) hipermenore, \% 6,67'sinde ( $\mathrm{n}=1)$ alt ekstremitede venöz ülserler, $\% 13,34$ 'ünde $(\mathrm{n}=2)$ menstrüel siklusta düzensizlik, \% 6,67'sinde ( $\mathrm{n}=1)$ UAS, \% 6,67'sinde $(\mathrm{n}=1)$ kronik obstrüktif akciğer hastalığ $1(\mathrm{KOAH})$, $\% 20$ 'sinde $(\mathrm{n}=3)$ hepatosteatoz mevcut olduğu belirlendi. 
RYGB uygulanan hastalarda ortalama kilo kaybı ilk 12 ayda yaklaşı $48,2 \mathrm{~kg}$ ve ilk 24 aylık periyotta $52,07 \mathrm{~kg}$ kaybı tespit edildi.Hastaların postoperatif dönemde vücut kitle indeksi(VKİ) değerlerinin ilk 12 aylık periyotta ortalama 32,16'ya ve ilk 24 aylık periyotta 30,95' e kadar gerilediği tespit edildi.Kilo kaybına paralel bir şekilde kronik hastalıkların zamanla düzeldiği gözlendi.Post operatif 1.yılda yaşam kalitesinin(SF-36 Quality Life formu ile değerlendirilen) belirgin şekilde arttığı gözlendi( $(p<0.05)$

Tartışma ve sonuç: Konvansiyonel RYGB ameliyatı ülkemizde ilk yapılan morbid obezite cerrahilerindendir. Morbid obezite tedavisinde hastaların kilo vermesini ve aynı zamanda obeziteye bağlı gelişen yandaş hastalıkların iyileşmesini sağlayan güvenli bir yöntem olup hastaların yaşam kalitesi üzerinde de anlamlı değişikliğe neden olmaktadır.

Anahtar Kelimeler: Morbid obezite, konvansiyonel roux en-y gastrik by-pass, obezite cerrahisi, yaşam kalitesi

\section{Giriș:}

RYGB prosedürü morbid obezite cerrahisinde güvenle ve etkili bir şekilde uygulanan bir prosedürdür(1,2). Konvansiyonel, laparaskopik ya da robotik olarak yapilabilir. Konvansiyonel RYGB,tüm bariatrik operasyonlar içerisinde zamanla en çok test edilen ve etkinliği kanitlanan operasyondur. Laparaskopik Roux En Y Gastrik Bypass(LRYGB ) cerrahisinden tek farkı giriş rotasının farklı olmasıdır. LRYGB'yi tercih etmeyen cerrahlar konvansiyonel RYGB'1 çok iyi sonuçlarla gerçekleştirmişlerdir. ABD'de 1990'lı y1lların en popüler operasyonuydu fakat zaman içerisinde hastaların laparakopiyi tercih etmelerinden dolayı ilgi azaldı. Aynı zamanda laparaskopik cerrahisi başarısız olmuş hastalar için konvansiyonel RYGB halen başarı ile yapılabilmektedir(3).

$\mathrm{Bu}$ çalışmada amaç, morbid obezite tedavisinde kullanılan cerrahi tedavi seçeneklerinden biri olan konvansiyonel RYGB yönteminin hastaların kilo kaybı üzerindeki etkilerini ve uzun dönem sonuçlarını değerlendirmek, eşlik eden hastalıkların giderilmesine katkılarını göstermeye çalışmaktır.

\section{Gereç ve Yöntem:}

Çalışmamızda Mart 2005 ile Şubat 2007 tarihleri arasinda RYGB uygulanan 2865 yaş arası 15 hasta retrospektif olarak değerlendirildi. Tüm hastalar cerrahi tedaviye American Society for Bariatric Surgery (ASBS) tarafindan belirlenmiş ölçütlere göre seçildi. Çalışmaya herhangi bir kabul edilebilir operasyon riskleri olan, vücut kitle indeksi (VKİ) $40 \mathrm{~kg} / \mathrm{m} 2$ 'nin üstünde veya
VKİ'si 30 ile 40 arasında olup aynı zamanda hipertansiyon (HT), diabetes mellitus (DM), uygu apne sendromu (UAS), diz ekleminde artritik dejenerasyon gibi eşlik eden hastalıkları olan hastalar alındı. Hormonsal hastalığı olan, alkol ile ilaç bağımlılığı bulunan olgular çalışma dışında tutuldu.

Çalışmaya alınan tüm hastaların ameliyat öncesi yaş, kilo, boy gibi demografik özellikleri, eşlik eden hastalıkları, kullandıkları ilaçlar sorgulandı. Ayrıca tüm hastaların kan örnekleri alınarak serum toplam kolesterol, düşük dansiteli lipotprotein (LDL), yüksek dansiteli lipoprotein (HDL), trigliserit, B12 vitamini, folik asit, insülin, C peptit analizleri yapıldı. Operasyon öncesinde safra kesesinde herhangi bir patoloji olup olmadığını değerlendirmek amaciyla abdominal ultrasonografi ve üst gastrointestinal sistemin durumunu belirlemeye yönelik özofagus, mide ve duodenum endoskopisi yapıldı. Hastalar hormonsal durum değerlendirilmesi açısından endokrinoloji, uyku-apne sendromu varlığının ve herhangi bir solunum fonksiyon bozukluğunun araştırılması için kulak burun boğaz ve göğüs hastalıkları, obezitenin psikolojik nedenli olup olmadığının tespiti amaçlı ruh ve sinir hastalıkları ve operasyona uygunluğun saptanması yönünden anesteziyoloji kliniklerine konsülte edildi.

Tüm hastalara ameliyat öncesi intramusküler enoksaparin sodyum $100 \mathrm{IU} / \mathrm{kg}$ (Clexane ${ }^{\circledR}$, Aventis Pharma, Türkiye) uygulaması ve bilateral antiembolik basınçlı çorap giydirilmesiyle tromboemboli profilaksisi sağland1. Tüm hastalara bir sonraki bölümde ayrıntılı olarak tarif edilmiş şekilde RYGB 
Tablo-1:Aylara göre FKK(\%) yüzde değişim değerleri ve ortalamaları

\begin{tabular}{|l|c|c|c|c|c|c|c|c|}
\hline Hasta Adı & pre-op & $\begin{array}{l}\text { İdeal } \\
\text { Ağılık(kg) }\end{array}$ & 1. ay & 3. ay & 6. ay & 12. ay & 18. ay & 24. ay \\
\hline 1.Hasta & 148 & 68.2 & 12,53 & 30,08 & 47,62 & 58.90 & 65.16 & 75,00 \\
\hline 2.hasta & 117 & 54.2 & 11,15 & 27,07 & 39,81 & 49,36 & 35,03 & 42,99 \\
\hline 3.hasta & 125 & 63.8 & 19,61 & 42,48 & 53,92 & 66.99 & 66,99 & 65,36 \\
\hline 4.hasta & 100 & 54.2 & 19,65 & 28,38 & 43,66 & 48.03 & 54,59 & 56,77 \\
\hline 5.hasta & 141 & 48.2 & 12,93 & 22,63 & 29,09 & 44.18 & 44,18 & 48,49 \\
\hline 6.hasta & 104 & 48.8 & 25,36 & 38,04 & 52,54 & 74.28 & 76,09 & 54,35 \\
\hline 7.hasta & 120 & 62.6 & 26,13 & 52,26 & 74,91 & 74,91 & 69,69 & 69,69 \\
\hline 8.hasta & 124 & 53 & 12,68 & 28.17 & 36.62 & 42,25 & 49,30 & 50,70 \\
\hline 9.hasta & 175 & 71 & 17.31 & 36.54 & 52,88 & 74,04 & 75,00 & 75,00 \\
\hline 10.hasta & 155 & 66.1 & 27,00 & 47.24 & 65,24 & 82,11 & 77,62 & 76,49 \\
\hline 11.hasta & 146 & 59.6 & 15,05 & 38,19 & 54,40 & 65,97 & 78,70 & 82,18 \\
\hline 12.hasta & 160 & 78 & 17,07 & 39,02 & 50,00 & 59,76 & 79,27 & 80,49 \\
\hline 13.hasta & 96 & 48.2 & 31.38 & 60,67 & 69,04 & 79,50 & 75,31 & 79,50 \\
\hline 14.hasta & 190 & 67.5 & 16,63 & 27,76 & 45,71 & 53,88 & 63,67 & 73,47 \\
\hline 15.hasta & 154 & 71 & 34,94 & 48,19 & 56,63 & 71,08 & 78,31 & 80,72 \\
\hline Ortalama & 137,00 & 68,25 & 19,29 & 37,90 & 52,53 & 65,29 & 65,98 & 67,41 \\
\hline
\end{tabular}

operasyonu uygulandi. Hastaların operasyon sonrasinda tromboemboli profilaksilerine 2 hafta daha devam edildi. Tüm hastalara postoperatif dönemde sıklikla eksikliğine rastlanan Fe, çinko, folik asit, vitamin B12 ve $\mathrm{Ca}$ içeren multivitamin preparatları destek amacıyla başlandi.

Operasyon süreleri ve hastaların hastanede kalış süreleri kaydedildi. Operasyon sonrası birinci, üçüncü, altıncı, on ikinci, on sekizinci ve yirmi dördüncü aylardaki vücut ağırlıkları, VKİ değişimleri ve fazla kilo kaybı yüzde (\% FKK) değerleri irdelendi. Eşlik eden hastalıklarındaki değişimler değerlendirildi.

Çalışmamızdan elde edilen veriler, NCSS 2000 programıla istatistiksel olarak incelendi. Elde edilen veriler ki-kare, Mann-Whitney U, Fisher Exact ve Student-t testi kullanılarak karşılaştırıldı. İkili değişkenler arasındaki bağıntıyı hesaplamak için Pearson Korelasyon Analizi kullanıldı. Sayısal değerler, ortalama \pm standart sapma (SS) şeklinde ifade edildi. $\mathrm{P}<0,05$ değeri istatistiksel olarak anlamlı kabul edildi.
Ameliyat Tekniği: Tüm hastalara genel anestezi altında supin pozisyonda göbeküstü median insizyonla laparotomi yapıldı. Cilt altı yağlı dokunun fazla olması dolayısıyla ekspojur sağlamak için cilt altı, geçici olarak inverte edildi. Genel eksprolasyonu takiben ligamentum Treitz'den itibaren $50 \mathrm{~cm}$ 'de jejunum $60 \mathrm{~mm}$ 'ik lineer stapler ile transekte edildi. Transekte edilen distal jejunum ansinda 150. cm'e Treitz den itibaren 50 . cm'deki proksimal jejunum, ansı yan yana olacak şekilde, lineer stapler ile jejunojejunostomi tamamland. Omentum orta hattan transvers kolona kadar transekte edildi. Küçük omentum sağ gastrofrenik ligamana kadar tamamen disseke edildi. Sonrasında sağ gastroözofageal bileşkenin 2 $\mathrm{cm}$ inferiorundan $60 \mathrm{~mm}$ 'lik lineer stapler ile mide, mideyi tam kat içersine alacak şekilde transvers olarak kesildi. Diğer lineer stapler, aks1 sol gastrofrerik ligamana doğru olacak şekilde vertikal olarak, mide tam kat kesilerek yaklaşık 25-30 ml hacminde üst gastrik poş oluşturuldu. Distal jejunum ansı antekolik olarak proximal gastrik poş ile $25 \mathrm{~mm}$ 'lik 
Tablo-2: Hastalar göre postoperatif yandaş hastalık seyirleri ve takip tablosu

\begin{tabular}{|c|c|c|c|c|}
\hline Cinsiyet & $\begin{array}{l}\text { Yaş } \\
\text { (yıl) }\end{array}$ & Yandaş Hast. & Post-op. Değişim & Takip \\
\hline$E$ & 27 & $\begin{array}{l}\text { Bilateral alt } \\
\text { ekstremite venöz } \\
\text { ülser }\end{array}$ & Düzelme & $\begin{array}{l}\text { 14. ayda abdominoplasti } \\
\text { yapıldı }\end{array}$ \\
\hline K & 63 & HT & $\begin{array}{l}\text { Düzelme (6. Ayda ilaçları } \\
\text { kesildi) }\end{array}$ & $\begin{array}{l}12 \text { ayda insizyonelherni } \\
\text { gelişti, onlay mesh } \\
\text { uygulandı ve abdominoplasti } \\
\text { yapıldı }\end{array}$ \\
\hline $\mathrm{K}$ & 31 & Yok & yok & \\
\hline $\mathrm{K}$ & 52 & HT & $\begin{array}{l}\text { Düzelme (3. ayda ilaçları } \\
\text { kesildi) }\end{array}$ & \\
\hline K & 54 & HT & $\begin{array}{l}\text { Halen antihipertansif tedavi } \\
\text { alıyor }\end{array}$ & İnsizyonel herni \\
\hline K & 44 & $\begin{array}{l}\text { İnsizyonel } \\
\text { Herni+KOAH }\end{array}$ & $\begin{array}{l}\text { solunumsal semptomları } \\
\text { postop } 1 \text { yılda geriledi }\end{array}$ & Nüks insizyonel herni \\
\hline $\mathrm{K}$ & 26 & Yok & yok & \\
\hline $\mathrm{K}$ & 54 & Vaginal kanama & Düzelme (6.ayda) & \\
\hline$E$ & 46 & $\begin{array}{l}\text { HT+Tip2 } \\
\text { DM+SleepApneSnd. }\end{array}$ & $\begin{array}{l}\text { Düzelme (3. ayda DM, CPAP } \\
\text { cihazinikullanmayibiraktı) }\end{array}$ & $\begin{array}{c}\text { 18.ayda abdominoplasti } \\
\text { yapıldı. }\end{array}$ \\
\hline$E$ & 36 & Yok & yok & \\
\hline K & 28 & $\begin{array}{l}\text { HT+Tip2 DM+ } \\
\text { menstrual } \\
\text { düzensizlik( pcos)+ } \\
\text { sık geçirilen } \\
\text { enfeksiyon+ hipotroidi }\end{array}$ & $\begin{array}{l}\text { Tip2 DM düzelme (3. ayda } \\
\text { ilaçları kesildi), } \mathrm{HT}^{\prime} \text { da } 6 \text { ayda } \\
\text { düzelme }\end{array}$ & $\begin{array}{c}\text { 19. ayda abdominoplasti } \\
\text { uygulandı }\end{array}$ \\
\hline$E$ & 29 & 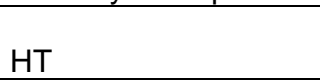 & $\begin{array}{l}\text { Düzelme (postop 4. ayda } \\
\text { ilaçları kesildi) }\end{array}$ & $\begin{array}{l}\text { 18.ayda abdominoplasti } \\
\text { yapıldı. }\end{array}$ \\
\hline $\mathrm{K}$ & 29 & $\begin{array}{l}\text { Tip2 } \\
\text { DM+Hepatosteatoz+ } \\
\text { infertilite }\end{array}$ & $\begin{array}{l}\text { Düzelme (3. ayda ilaçları } \\
\text { kesildi) }\end{array}$ & \\
\hline$E$ & 24 & Yok & & \\
\hline$E$ & 27 & HT & $\begin{array}{l}\text { antihipertansif tedavi postop } 6 \text {. } \\
\text { ayda stoplandı. }\end{array}$ & \\
\hline
\end{tabular}

Tablo -3: Obezite Tedavisinde Gastric Bypass Ameliyatı Geçirmiş Hastaların Ameliyat Öncesi ve Sonrasında Yaşam Kalitelerinin Değerlendirilmesi

\begin{tabular}{llll}
\hline SF 36 Quality Life & $\begin{array}{l}\text { Preop } \\
\text { Ort } \pm \text { SD }\end{array}$ & $\begin{array}{l}\text { Postop 1.yıl } \\
\text { Ort } \pm \text { SD }\end{array}$ & $p$ \\
\hline \hline${ }^{+}$Fiziksel Fonksiyon & $37,08 \pm 23,88$ & $90,83 \pm 9,49$ & $0,001^{* *}$ \\
${ }^{+}+$Fiziksel Rol Güçlüğü & $12,66 \pm 20,29$ & $85,41 \pm 29,11$ & $0,003^{* *}$ \\
${ }^{+}$Ağrı & $45,25 \pm 19,16$ & $76,83 \pm 26,50$ & $0,001^{* *}$ \\
${ }^{+}$Genel Sağlık & $32,58 \pm 21,44$ & $72,50 \pm 19,60$ & $0,001^{* *}$ \\
${ }^{+}$Enerji & $38,75 \pm 22,97$ & $78,08 \pm 22,12$ & $0,002^{* *}$ \\
${ }^{+}$Sosyal Fonksiyon & $44,79 \pm 29,89$ & $67,71 \pm 36,33$ & 0,096 \\
${ }^{++}$Emosyonel Rol Güçlüğü & $13,88 \pm 30,00$ & $77,78 \pm 32,82$ & $0,004^{* *}$ \\
${ }^{+}$Mental Sağlık & $49,33 \pm 26,27$ & $71,00 \pm 16,89$ & $0,050^{*}$ \\
\hline
\end{tabular}


sirküler stapler kullanılarak gastrojejunostomi tamamland1. Gastrojejunostominin proksimaline kadar ilerletilen nazogastrik sondadan serum fizyolojik ile dilüe edilmiş metilen mavisi verilerek anastomoz hattı ve mide poşu kontrol edildi. İncebarsak mezosundaki açıklıklar absorbable sütür materyali ile sütüre edildi. Gastrojejunostomi komşuluğuna 1 adet Jackson pratt dren yerleştirildi. Genel ve kanama kontrolünü takiben batın usulüne uygun olarak kapatıldı. Cilt altına 1 adet hemovac dren yerleştirildi. Cilt stapler ile kapatılarak operasyon sonlandırıldı.

\section{Sonuçlar:}

Çalışmada 6'sı (\% 40) erkek, 9'u (\% 60) kadın toplam 15 hastaya ait veriler değerlendirildi. Hastaların yaş ortalaması, tüm olgularda $38 \pm 12,90 \quad(24-63)$ yil olup erkeklerde 31,5 $\pm 8,16$ (24-46) yil kadinlarda 42,33 $\pm 14,02$ (26-63) y1l olarak saptand1.

Hastaların eşlik eden hastalıklar açısından ameliyat öncesi değerlendirilmelerinde; \% 47'sinde $(\mathrm{n}=7)$ HT, $\%$ 20'sinde $(\mathrm{n}=3)$ Tip II DM, \% 6,67'sinde $(\mathrm{n}=1)$ hipermenore, \% 6,67'sinde $(\mathrm{n}=1)$ alt ekstremitede venöz ülserler, \% 13,34'ünde $(n=2)$ menstrüel siklusta düzensizlik, \% 6,67'sinde ( $\mathrm{n}=1) \mathrm{UAS}$, $\%$ 6,67'sinde $(\mathrm{n}=1)$ kronik obstrüktif akciğer hastalığ $\quad(\mathrm{KOAH}), \quad \% \quad 20$ 'sinde $\quad(n=3)$ hepatosteatoz mevcut olduğu belirlendi.

Hastalara uygulanan operasyonlara ait verilerin değerlendirilmesi yapıldığında ortalama ameliyat süresi $210 \pm 34,52$ (180240 ) dakika olarak saptand1. Hastaların hastanede kalış süreleri ortalaması $8,27 \pm 2,51$ (7-17) gün olarak tespit edildi. Hastalarda operasyon sonrası erken ve geç dönemde mortalite tespit edilmedi. Hastalarda operasyon sirasinda herhangi bir komplikasyon gelişmedi.

Uzun dönem komplikasyon olarak operasyon sonrasinda hastaların 2'sinde $(\% 13,34)$ yara yeri enfeksiyonu, birinde $(\% 6,67)$ ikinci haftada pulmoner emboli gelişti. Pulmoner emboli gelişen hastaya 2 hafta medikal tedavi uyguland1. Pulmoner emboli gelişen hastada operasyondan sonraki birinci yılda hipokrom mikrositer anemi gelişti ve paranteral demir tedavisi uygulanarak başarılı şekilde tedaviedildi. Daha geç dönemli takiplerde bir hastada operasyondan iki hafta sonra diare tespit edildi. Konservatif yaklaşım ve uygun s1v1-elektrolit yerine koyma tedavisiyle iki haftalık bir sürede şikâyetleri geriledi.

Geç dönemde en sık görülen komplikasyonlardan olan insizyonel herni üç hastada görüldü. Bir hastada birinci yılda diğer ikisinde de ikinci yılda tespit edildi. Operasyonun başarısını değerlendirmek için hastaların kilo değișimleri incelendi. Hastaların operasyon öncesinde ve sonrasındaki birinci, üçüncü, altıncı, on ikinci, on sekizinci ve yirmi dördüncü aylardaki kiloları, VKI' lerinin takibi yapılarak kilo kayıpları, VKI' de ve \%FKK' de meydana gelen değişimleri karşılaştırıldı. (tablo -1) RYGB uygulanan hastalarda ortalama olarak ilk 12 ayda yaklaşı1k $48,2 \mathrm{~kg}$ ve ilk 24 aylık periyotta 52,07 kg kayb1 tespit edildi. Hastaların postoperatif dönemde VKİ değerlerinin ilk 12 aylık periyotta ortalama 32,16 'ya ve ilk 24 aylik periyotta 30,95 ' e kadar gerilediği tespit edildi.

Ayrica RYGB uygulanan hastalarda ilk 12 aylık dönemde hızlı bir VKİ kaybı gerçekleşmekte ve ivmesi azalmakla birlikte VKİ düşüşü 24. aya kadar da devam etmektedir. 12. aydan sonra \%FKK değerinde artışta bir ivme azalması tespit edilmiştir. Serum B12 ve folat değerlerinde dalgalanma izlenmiş, bu da multivitamin replasmanına bağlanmıştır. Serum insulin ve C-peptid düzeylerinde düşüş izlenmiş olması kan şekeri regülasyonunda iyi yönde metabolik bir değişim olarak dikkati çekmiştir. Kan hemoglobin değerlerinde anlamlı değişiklik izlenmemiştir.

Obezitenin meydana getirdiği vücut imaj bozukluklarının giderilmesi amacıyla beş hastaya plastik cerrahi kliniğinde operasyondan ortalama 16,2 (12-18) ay sonra abdominoplasti operasyonu uyguland. RYGB' nin eşlik eden hastalıklara etkisi değerlendirilmiştir. Hastaların operasyon sonrası takiplerinde hipertansiyon açısından ilaç tedavisi almakta olanlardan 6'sında medikal tedavi ortalama 4,6 (3-6) ayda sonlandırıldığı görülmüştür. Operasyon öncesi hipertansiyon açısından tedavi almakta 
olan diğer hasta ise düşük doz ilaç tedavisine devam ettiği tespit edilmiştir. DM açısından medikal tedavi almakta olan hastaların 3'ünde ortalama 3 ayda (2-4 ay) medikal tedaviye gerek kalmamıştır. Operasyon öncesi dönemde UAS tanısıyla sürekli pozitif basınç uygulamas1 (CPAP-Continuous Positive Airway Pressure) tedavisi almakta olan hasta, operasyon sonrası 6. ayda CPAP kullanmayı bırakmıştır. Preoperatif dönemde bilateral alt ekstremitede venöz ülserleri bulunan hastanın venöz ülserleri postoperatif dönemde birinci yılda tamamen gerilediği saptanmıştır. İleri derecede KOAH tanısiyla medikal tedavi almakta olan aynı zamanda pulmoner emboli sebebiyle postoperatif dönemde takip ve tedavi edilen hastanın solunumsal sikıntıları postoperatif birinci yıla kadar sürmüş olduğu izlenmiştir. Hipermenore şikâyetli hastanın postoperatif 6 . ayda menstrüel siklusları düzene girmiştir.(tablo-2)

Tüm hastalara ameliyat öncesi ve ameliyattan 1 y1l sonraki dönemde SF-36 Quality Life formu (sağlıkla ilgili yaşam kalitesini ölçen form) ile değerlendirildi. Bu form sekiz alt ölçekten oluşmuş olup hastaların fiziksel fonksiyon, mental sağlık, sosyal sağlık, fiziksel rol, emosyonel rol, zindelik, bedensel ağrı ve genel sağlı parametrelerini irdelemiştir. Elde edilen sonuçlar \%95'lik güven aralığında, anlamlılık $\quad \mathrm{p}<0.05$ düzeyinde istatistiksel olarak değerlendirildi. Hastaların ameliyat öncesi ve sonrası SF-36 Quality Life değerlendirmesi Tablo-3 de görülmektedir.

\section{Tartışma:}

Çalışmamızda RYGB uygulanan tüm hastalarda gerek kilo kaybı gerek de VKI' de ve $\%$ FKK' de istatistiksel olarak anlaml düşüşler olduğu gösterilmiştir. Aynı zamanda operasyondan 1 yil sonra yapilan SF-36 Quality ölçeğinde hastaların fiziksel fonksiyon, mental sağlık,fiziksel rol, emosyonel rol, zindelik, bedensel ağrı ve genel sağlık parametrelerinde belirgin düzelme gözlenmiştir $(\mathrm{p}<0.05)$. Hastaların operasyon sonrasında başlayan kilo kayıpları uzun dönemde istikrarlı bir şekilde devam etmiş olması operasyonun sadece geçici bir çözüm olmadığını ortaya koymaktadır.

Gastrik bypass ameliyatlarının ilki 1969 yılında Mason ve Ito tarafindan tarif edilmiştir(4). Bu ameliyat daha sonraları pek çok cerrah tarafından modifiye edilerek uygulanmıştır(5,6). RYGB 1990'lı yıllardan beri özellikle ABD' de s1k tercih edilen obezite ameliyatları arasındadır(7). Bu ameliyatta hastalarda 20-30 $\mathrm{ml}$ üst gastrik poş oluşturulmakta ve bu şekilde distal büyük mide, duodenum ve proksimal jejunum bypass edilmektedir. $\mathrm{Bu}$ sayede kilo kayb1 kombine olarak restriksiyon ve malabsorbsiyon oluşturularak sağlanmaktadır. $\mathrm{Bu}$ anatomik değişiklikler hastalarda alınan gidanın miktarının azaltılmasını sağlamakta aynı zamanda glukoz ve karbonhidrattan zengin gidaların emilimini engelleyerek kilo kaybına neden olmaktadır(8). Çalışmamızda morbit obezite nedeniyle RYGB uygulanan tüm hastalarda yaklaşık $30 \mathrm{ml}$ üst gastrik poş oluşturuldu ve uzun ans gastrik bypass uyguland. Günümüzde obezite cerrahisi uygulanan hastalarda esas amaç; hem hastaların kilo vermesini sağlamak hem de hastanın yaşam kalitesini yükseltmektir. Obezite cerrahisi uygulanan ameliyatlar arasinda RYGB \% 65'lik bir oranla dünyada ilk sirada yer almaktadır(9). Hastaların kilo vermesinde ve yandaş hastalıkların azaltılmasında oldukça etkili olmaktadır $(10,11)$. Yapılan birçok çalışmada RYGB sonrasında 2-5 yıllık takiplerinde $\%$ 65-75 oranında \%FKK olduğu belirtilmektedir(10). Bizim çalışmamızda da 2 yıllık takiplerde \% 67,41'lik \%FKK değişimi saptanmıştır. $\mathrm{Bu}$ bulgu literatürde verilen oranlarla uyumludur. Yine benzer bir oran Diniz ve arkadaşları 2008 yılında yaptıkları çalışmada gösterilmiştir. 170 hastalık bir seride postoperatif birinci yıl \% FKK değerini $\%$ 67,4 ve 146 hastalık bir seride postoperatif 2. yılın sonunda \% FKK değerini \% 72,7 olarak belirtmişlerdir(12). Parikh ve arkadaşları 2007 yılında yayınlanan, 2001 ile 2004 yılları arasinda 53 RYGB uygulanan hasta için postoperatif 1. y1l \% FKK \% 66, postoperatif 2. y1l için \% FKK değeri \% 68 olarak belirtmişlerdir(13). Çalışmamızda 
ameliyat öncesi dönemde ortalama 49.30 $\mathrm{kg} / \mathrm{m}^{2}$ olarak ölçülen VKİ' nin ameliyat sonras1 24.ayda $30.95 \mathrm{~kg} / \mathrm{m}^{2}$ olduğu görülmüştür.

Obezite cerrahisi uygulanan hastaların takiplerinde yandaş hastalıkların başarılı bir şekilde tedavi edildiği görülmektedir(14). RYGB ciddi obeziteye bağlı olarak gelişen tip 2 diyabet tedavisinde $\% 85$ oranında başarı sağlamaktadır(15-18). Bizim çalışmamızda da DM' si olan hastaların tamamının operasyon sonrasi 2. yılda medikal tedaviyi bıraktıkları saptanmıştır. Aynı şekilde bu grup hastalarda tedavisi oldukça zor olan HT' nin iyileştirilmesi veya tamamen ortadan kaldırılması uygulanan ameliyat sonucunda mümkün olabilmektedir. Çalışmaya dahil edilen 7 hastanın 6's1 ortalama 4,6 ayda medikal tedaviyi bırakmış biri ise kullandığ 1 ilaç dozunu azaltmıştır. Dislipidemi, özellikle hipertrigliseridemi ve yükselmiş kolesterol/LDL seviyeleri uygulanan birçok medikal tedaviye göre uzun dönemde daha başarılı ve güvenilir bir şekilde tedavi edilmektedir(11). Hastaların kolesterol değerleri ortalama olarak 191 den 150(kadınlarda 162,67 erkeklerde 132,17) ye, LDL düzeyleri ortalama olarak 115 ten 85(kadınlarda 91,47 erkeklerde 74,57)'e düşüş göstermiştir. Yan ve arkadaşlarının 2008 yılında yayınlanan bir çalışmalarında obezitenin sebep olduğu komorbititelerde RYGB sonrası gerileme olduğu belirtilmiştir. Yine aynı çalıșmada 2 yıllık \% FKK oranlarını $\% 58$ olarak belirtmişlerdir(19). Zlabek ve arkadaşlarının 168 hastalık bir grup için preoperatif 1 yıl ve postoperatif 2 yıllık takiplerinde total kolesterol, LDL, TG değerlerinde anlamlı azalma tespit etmişlerdir. Bu çalışmada HDL de anlamlı sayılabilecek bir artma tespit edilmiştir(20). Çalışmamızda ayrıca literatürde bildirilmeyen obeziteye bağlı olarak gelişen bilateral alt

\section{REFERENCES}

1. Fernandez Jr AZ, DeMaria EJ, Tichansky DS, et al. Experience with over 3,000 open and laparoscopic bariatric procedures: multivariate analysis of factors ekstremite ülserlerinin postoperatif dönemde kaybolduğu görüldü. Hastalardan birinde obeziteye bağlı olarak gelişen uyku apne sendromu dolayısiyla Continious Positive Airway Pressure (CPAP) cihazı kullanıyorken ameliyat sonrası dönemde solunumsal sorunlarının tedavi olduğu görüldü.

RYGB uygulanan hastaların \% 10-15' inde kilo kaybı ve yandaş hastalıkların azalmasında yetersizlik olabilmektedir(21). Bunun nedeni yetersiz restriksiyon (dilate üst gastrik poş, gastrogastrik fistül), gıda alımına adapte olamama, psikososyal stres, preoperatif $\mathrm{VKI}>50 \quad \mathrm{~kg} / \mathrm{m}^{2}$ ve genetik predispozisyondur(22). Çalışmamızda gastrik bypass uygulanan hastalarda yapilan takiplerde başarısız kilo kaybı görülmedi. Yaptığımız takiplerde literatürle benzer sonuçlara ulaşılmasının uygun hasta seçimine ve uyguladığımız ameliyat tekniğine (50/150 uzun urve RYGB) bağlı olduğu düşünüyoruz. Günümüzde konvansiyonel cerrahinin yerini laparaskopik ve robotik cerrahi almıştır.Aiolfi ve ark.yaptıg1 metaanalizde laparaskopik ve robotik RYGB konvansiyonel cerrahi ile kıyaslandığında 30 günlük mortalite, hayat boyu görülen komplikasyonlar,enfeksiyöz ve pulmoner komplikasyonlar açısından daha güvenlidir(23).

Limitasyonlar: Çalışmamız retrospektif olup hasta sayısı göreceli olarak azdır. Ancak ülkemizde morbid obezitesinin yapıldığ 1 ilk yıllar göz önüne alındığında, "emekleme dönemi" için hatrı sayılır bir rakama ulaşılmıştır.

Sonuç: Konvansiyonel RYGB ameliyatını morbit obezite tedavisinde hastaların kilo vermesini ve aynı zamanda obeziteye bağlı gelişen eşlik eden hastalıkların iyileşmesini sağlayan güvenli bir yöntem olup hastaların yaşam kalitesi üzerinde de anlamlı değişikliğe neden olmaktadir

related to leak and resultant mortality. Surg Endosc 2004;18(2):193-7.

2.Morino M, Toppino M, Forestieri P, Angrisani L, Allaix ME, Scopinaro N. Mortality after bariatric surgery: analysis of 13,871 morbidly obese patients from a national registry. Ann Surg 2007;246(6):1002-7 
3.Brunicardi FC, Geeta L, Orlo H.C. Obezitenin Cerrahi Tedavisi. Schwartz Cerrahinin İlkeleri(10. Baskı). 2016;1118

4. Mason EE, And Ito, C.:Gastric bypass. Ann Surg, 1969;170:329

5. Griffen WO, Jr Young VL and Stevensen CC: A prospective comparison of gastric and jejunoileal bypass procedures for morbit obesity. Ann Surg. 1977; $186: 500$

6. Torres JC, Oca CF, Garrison RN. Gastric bypass: Rouxen-Y gastrojejunostomy from the lesser curvature. South Med J. 1983;76:1217-21.

7. Feng JJ, Gagner M, Pomp A, Korgaonkar NM, Jacob BP, Chu CA, Voellinger DC, Quinn T, Herron DM, Inabnet WB. Effect of standard vs extended Roux limb length on weight loss outcomes after laparoscopic Roux-en-Y gastric bypass. Surg Endosc. 2003;17:105560

8. Inabnet WB, Quinn T, Gagner M, Urban M, Pomp A. Laparoscopic Roux-en-Y gastric bypass in patients with $\mathrm{BMI}<50$ : a prospective randomized trial comparing short and long limb lengths.Obes Surg. 2005;15:51-7

9. Schauer P, Gastric bypass for severe obesity: Approaches and outcomes,Surg Obes Relat Dis 2005;1:297-300

10. Dhabuwala A, Canan RJ, Stubbs RS. Improvement in co- morbitities followingweight loss from gastric bypass sur- gery. Obes Surg. 2000;10:428-35

11. Tweddle EA, Woods S, Blamey S. Laparoscopic gastric banding: safe and modestly successful. ANZ J Surg 2004;74:191-194.

12. Diniz MD, Passos VM, Barreto SM, Linares DB, de Almeida SR, Rocha AL, Diniz MT. Different Criteria for Assessment of Roux-en-Y Gastric Bypass Success: Does Only Weight Matter? Obes Surg. 2008

13. Parikh M, Ayoung-Chee $P$, Romanos $E$, Lewis $N$, Pachter HL, Fielding G, Ren C. Comparison of rates of resolution of diabetes mellitus after gastric banding, gastric bypass, and biliopancreatic diversion. J Am Coll Surg. 2007;205:631-5.

Corresponding author e-mail: ergunyuksel2@gmail.com

Orcid ID:

Ergun Yüksel 0000-0001-8425-1365

Mehmet Akif Üstüner 0000-0003-4087-555X

Mehmet Mihmanlı 0000-0002-4829-4728

Doi: $10.5505 /$ aot.2021.94834
14. Simard B, Turcotte H, Marceau P et al. Asthma and sleep apnea in patients with morbit obesity: outcome after bariatric surgery. Obes Surg. 2004;14:1381-8

15. Pories WJ, Swanson MS and MacDonald KG Jr et al, Who would have thought it? An operation proves to be the most effective therapy for adult-onset of diabetes mellitus, Ann Surg. 1995; 222:339-352.

16. Sjostrom $L$, Lindroos $A K$ and Peltonen $M$ et $a$, Lifestyle, diabetes, and cardiovascular risk factors ten years after bariatric surgery, $N$ Engl J Med. 2004;351:2683-2693.

17. Buchwald $H$, Avidor $Y$ and Braunwald $W$ et al., Bariatric surgery: A systematic review and metaanalysis, JAMA. 2004;292:1724-1737.

18. Schauer P.R., Burguera B. and Ikramuddin S. et al., Effect of laparoscopic Roux-en-Y gastric bypass on type II diabetes mellitus, Ann Surg. 2003;238:467-485.

19. Yan E, Ko E, Luong V, Wang HJ, Romanova M, Li Z Long-term changes in weight loss and obesity-related comorbitities after Roux-en-Y gastric bypass: a primary care experience. Am J Surg. 2008;195:94-8

20. Zlabek JA, Grimm MS, Larson CJ, Mathiason MA, Lambert PJ, Kothari SN. The effect of laparoscopic gastric bypass surgery on dyslipidemia in severely obese patients. Surg Obes Relat Dis. 2005;1:537-42

21. Zoppini G, Verlato G, Leuzinger C, Zamboni C, Brun

$\mathrm{E}$, Bonora $\mathrm{E}$, Muggeo $\mathrm{M}$. Body mass index and the risk of mortality in type II diabetic patients from Verona. Int J Obes Relat Metab Disord. 2003;27:281-5

22. Buchwald H, Buchwald JN. Evolution of operative procedures for the management of morbit obesity 1950-2000. Obes Surg. 2002;12:705-17

23.Aiolfi A, Tornese S, Bonitta G, Rausa E, Micheletto G, Bona D. Roux-en-Y gastric bypass: Systematic review and Bayesian network meta-analysis comparing open, laparoscopic, and robotic approach. Surg Obes Relat.Dis.2019;15:985-994.. 